\title{
FINANCIAMENTO IMOBILIÁRIO NO BRASIL: Uma análise histórica compreendendo o período de 1964 a 2013, norteada pelo arcabouço teórico pós-keynesiano e evolucionário.
}

\author{
Ewerton Gouveia Ferreira Pinto \\ Graduando em Ciências Econômicas da Universidade Federal da Paraíba (UFPB) \\ Endereço para contato: Nordwall ,50. Krefeld - Alemanha \\ CEP: 47798- E-mail: ewerton.gfpinto@student.uni-siegen.de
}

Recebido em 01 de fevereiro de 2016. Aceito em 12 de fevereiro de 2016.

\section{RESUMO}

Entre 1964 a 2013 foram criados no Brasil dois sistemas de financiamento com o objetivo e solucionar o problema do déficit habitacional. O primeiro foi o Sistema Financeiro da habitação (SFH), criado em 1964 que tinha seu foco direcionado para o financiamento de imóveis residenciais para a população de baixa renda, o segundo foi o Sistema de financiamento Imobiliário (SFI), criado em 1997, que tinha um caráter mais amplo e funcionava sobre uma lógica de financiamento de mercado. Por fatores característicos da economia brasileira o SFI não conseguiu galgar grandes resultados, de modo que a maioria dos financiamentos para a habitação é realizada através do SFH. Os programas do Governo Federal nos últimos anos tiveram papel fundamental na expansão do financiamento habitacional. Esse aumento do crédito vem proporcionando um grande crescimento no setor imobiliário e provocando elevação dos preços dos imóveis. Todo esse processo histórico revela inovações nas formas de financiamento e evolução no âmbito dos sistemas, por isso a análise realizada partiu dos conceitos de duas teorias econômicas, a Hipótese de Fragilidade Financeira e a teoria Evolucionaria.

Palavras-chave: Financiamento Habitacional. Crédito Imobiliário. Expansão Imobiliária

\begin{abstract}
Between 1964 and 2013 were created in Brazil two financing systems in order to solve the problem of housing deficit. The first one was the Housing Finance System (HFS), created in 1964, which focus was directed to the financing of residential properties for low-income population, the second one was the Real Estate Financing System (REFS), created in 1997 that had a broader character and worked on the logic of market financing. In reason of characteristic factors of the Brazilian economy REFS could not climb great results, so that most of the housing loans are accomplished through the HFS. The federal government programs in recent years played a key role in the expansion of housing financing. This credit enhancement is providing tremendous growth in real estate and is causing an increase of property prices. All this historical process reveals innovations in the forms of funding and evolution within systems, in this way, the analysis came from the concepts of two economic theories, Hypothesis Financial Fragility and evolutionary theory.
\end{abstract}

Key-words: Housing loans. Mortgage Loan. Property Expansion.

Econ. e Desenv., Santa Maria, vol. 27, n.2, p. 276 - 296, jul. - dez. 2015 RE\&D 


\section{INTRODUÇÃO}

$\mathrm{Na}$ última década a expansão imobiliária esteve no centro das notícias relacionadas a crescimento econômico e crise financeira. Foi no setor imobiliário que eclodiu, em 2008, a maior crise do capitalismo moderno, iniciada nos Estados Unidos da América. A crise chegou a atingir as principais economias do mundo, em alguns lugares os efeitos danosos da crise foram experimentados mais amargamente, como é o caso dos países europeus, em outros, todavia, o efeito foi um pouco mais brando como, por exemplo, no caso brasileiro. O ponto central do problema estava no sistema altamente sofisticado de financiamento que os EUA desenvolveram nas últimas décadas. $\mathrm{O}$ setor imobiliário se constituiu na forma de manifestação da crise que teve suas causas originadas no sistema financeiro.

O financiamento é um instrumento essencial na promoção do desenvolvimento imobiliário, pois, devido aos altos custos dos imóveis, é necessário que existam fontes geradoras de créditos direcionadas a este segmento. A compra de um imóvel se constitui no maior ou no único grande investimento realizado durante toda a vida de um indivíduo, sem o crédito, esse sonho se torna praticamente impossível.

No Brasil, já há algum tempo, precisamente a partir de 2007, ficou comum observarmos diariamente nos jornais, notícias relacionadas à forte expansão do mercado imobiliário. Em todo o território nacional a construção civil passou a ser o alvo preferencial nas decisões de investimentos produtivos. Tornou-se comum, pessoas que possuem trabalhos fixos e relativamente bem remunerados, utilizar a construção como uma forma alternativa e rápida de enriquecimento.

Segundo a FGV (2008), a construção civil já havia se tornado um dos principais motores do crescimento econômico nacional a partir de 2005, comparando o crescimento entre os anos de 20052006 e 2006-2007 enquanto que o Brasil cresceu 3,8\% e 5,4\% a cadeia produtiva da construção civil cresceu $4,7 \%$ e $7,9 \%$ respectivamente. Esse crescimento produziu reflexo direto no investimento realizado na construção, que cresceu 22,5\%, no emprego formal, que foi ampliado para $8 \%$, na arrecadação de tributos e até mesmo na valorização salarial, embora para esta última sempre em níveis mais baixos.

O trabalho assume a hipótese de que são as inovações institucionais promovidas pelos governos, que reorganizam o funcionamento do mecanismo seletivo dos mercados, e as inovações financeiras criadas pelas instituições privadas, ampliando a diversidade de produtos e mercados, que determinam a dinâmica evolutiva do sistema de financiamento habitacional e imobiliário. A evolução requer a operação dos dois mecanismos (inovação e seleção). Se as inovações institucionais criadas pelo governo não estimularem a inovatividade das empresas, ou se exacerbarem a punição aos que cometerem erros, o mercado não evoluirá.

Diante da característica temporal dos empréstimos, ao fazer uma análise mais aprofundada, fica claro a necessidade de utilizar uma teoria que trate o tempo como um fator importante no processo de tomada de decisão. Na teoria de Minsky o tempo é fator primordial, é devido às expectativas de como estará à economia no futuro que os agentes tomam decisões no presente. As mudanças de posturas financeiras dos agentes é consequência direta dos momentos de transformação que a economia vai passando ao longo do tempo.

Os processos de mudanças que ocorreram no âmbito do Sistema Financeiro da Habitação (SFH) são caracterizados como processos evolutivos, novas tecnologias são introduzidas, e tais tecnologias ou "inovações financeiras" remetem novamente as características da teoria de Minsky, mas também encontram espaços na teoria evolucionária.

O Sistema de Financiamento Imobiliário (SFI) se constituiu na tentativa de promover uma mudança de paradigma, para o qual o sistema velho é substituído pelo novo. Esse conceito de paradigma tecnológico é trazido pelos teóricos evolucionários e se torna uma forte ferramenta para a

Econ. e Desenv., Santa Maria, vol. 27, n.2, p. 276 - 296, jul. - dez. 2015 RE\&D 
construção de um argumento sólido a respeito das mudanças na forma de financiamento imobiliário proposto no Brasil.

Diante desses fatos, foi realizada uma análise a partir de dois arcabouços teóricos, são eles: a Hipótese de Fragilidade Financeira e a teoria evolucionaria Neo-Shumpeteriana. Através dessas duas teorias é buscado compreender a dinâmica do financiamento imobiliário no Brasil sobre uma lógica de evolução nos processos inovativos financeiros.

O método foi explorado através da revisão da literatura que consistiu em uma densa leitura e utilização da base de dados de fontes como: Banco Central do Brasil, Instituto Brasileiro de Geografia e Estatística (IBGE), Instituto de Pesquisa Econômica Aplicada (IPEA); Caixa Econômica Federal (CEF) e Associação Brasileira das Entidades de Crédito Imobiliário e Poupança (ABECIP).

Nesse trabalho, além da introdução, na seção dois é realizada uma análise teórica financiamento imobiliários, na seção três busca-se extrair os motivos que proporcionaram o surgimento do SFH e do SFI, além de abordar todos o processo de desenvolvimento desses sistemas. Na quarta seção é realizada uma análise contemporânea da situação do crédito imobiliário. Por fim, são realizadas as considerações finais.

\section{A HIPÓTESE DA FRAGILIDADE FINANCEIRA E TEORIA EVOLUCIONÁRIA}

Minsky desenvolveu um arcabouço teórico poderoso capaz de diagnosticar a presença de um processo endógeno dentro do sistema financeiro. Esse processo seria uma reavaliação natural dos riscos existentes no mercado. O fato é que, em momentos de estabilização econômica, os riscos das operações naturalmente tendem a ser cada vez menores, por isso, o "mercado" tem a percepção de que a robustez econômica permite uma maior expansão do nível de atividade que está sendo realizada. A estabilização acaba provocando um ambiente favorável à maior especulação, que gerará, no futuro, operações financeiras cada vez dependentes de uma larga liquidez no mercado financeiro, que, consequentemente, irão provocar uma fragilização na economia.

A hipótese de Instabilidade Financeira está submetida às características de uma economia capitalista possuidora de um sistema financeiro forte, complexo, sofisticado e que esteja em constante evolução, variando entre períodos de estabilidade e instabilidade. Essas alternâncias de comportamento são inerentes ao próprio sistema capitalista. A instabilidade pode ser ocasionada por problemas inflacionários, bolhas especulativas ou qualquer fator que provoque uma perturbação no sistema. O fato é que a instabilidade provoca a necessidade de um regime de estabilidade, necessariamente esses fatores perturbadores deverão ser eliminados, seja por intervenção estatal ou até mesmo por auto-organização dos mercados. É provável que em consequência das medidas adotadas para buscar a estabilidade, surja um novo momento de baixa atividade econômica, que mais tarde será revertida devido à busca dos interesses próprios dos agentes que acabará gerando um novo ciclo de expansão, provocando novamente uma nova onda especulativa, o que ao longo do tempo irá dando origem a novos modelos de "expansões incoerentes e contrações desastrosas" (LOURENÇO, 2006).

Em momentos de "boom", aumenta a necessidade de expandir o crédito, assim como são ampliadas as necessidades das Autoridades Monetárias em criar mecanismos de controle para o relacionamento entre bancos e clientes. É nesse momento que surgem e se desenvolvem as inovações financeiras, mediante o estímulo do interesse mútuo dos clientes, que desejam ampliar seu consumo ou adquirir crédito para investimento, e dos bancos que desejam ampliar seus lucros. Esses novos mecanismos irão driblar os controles impostos (LEITE, 2011).

As inovações financeiras criadas para expandir o crédito acabam provocando uma incapacidade, por parte do Banco Central, de influenciar o processo de criação de moeda, provocando assim um maior risco sistêmico (CINTRA; CAGNIN apud LEITE, 2011). É com base nesses

RE\&D Econ. e Desenv., Santa Maria, vol. 27, n.2, p. 276 - 296, jul. - dez. 2015 
argumentos que Minsky demonstra que os novos arranjos criados são uma resposta ao controle das Autoridades Monetárias (LEITE, 2011).

Conforme a hipótese da instabilidade financeira, a economia capitalista caracteriza-se por um sistema financeiro sofisticado e complexo, e seu desenvolvimento ocorre acompanhado por trocas de dinheiro presente por dinheiro futuro. É uma economia inerentemente instável, que apresenta um endividamento crescente em função de sua necessidade de financiar $o$ investimento em um ambiente de crédito barato, o que faz com que, de tempos em tempos, gere inflações e deflações de dívidas. Desse modo, mostra um comportamento cíclico, em que todos os ciclos são gerados endogenamente e são transitórios (BAHRY; GABRIEL, 2010, p. 31).

Para Minsky existem dois tipos de riscos que afetam a economia, um é o risco do devedor e o outro é o risco do credor. Esses riscos irão influenciar diretamente os preços de oferta e demanda dos ativos. realizado, já que em um ambiente de incerteza é impossível prever qual será o resultado do investimento e no risco de liquidez, pois o devedor tem receio de ficar ilíquido e não conseguir honrar os compromissos financeiros do empréstimo contraído. Com relação ao credor, o risco está associado ao desapontamento das expectativas, do receio de adquirir ativos de longo prazo usando passivos de curto prazo e o risco moral (Bahry; Gabriel, 2010).

Durante os ciclos econômicos os agentes vão adotando diferentes posturas. Essa mudança de comportamento está ligada ao momento de liquidez que a economia está passando. É importante deixar claro que em um mesmo ponto do tempo, agentes diferentes possuem posturas diferentes, bem como, ao longo do tempo, o mesmo agente muda suas posturas financeiras. Na realidade é a mudança de postura dos bancos, que passam a avaliar que o risco de iliquidez caiu, que amplia a liquidez, e a mudança de postura dos investidores, que também passam a achar que o risco de iliquidez caiu, os leva a aumentar o endividamento. Este duplo movimento amplia a fragilidade financeira, resultado de uma queda na percepção do risco.

É nesse contexto de avaliação de riscos, o risco de ficar ilíquido no futuro quando precisar pagar o serviço financeiro da divida e os rendimentos esperados forem insuficientes e não conseguir captar liquidez no mercado financeiro, que Minsky classifica os agentes de acordo com três posturas: hedge, especulativo e ponzi.

i) hedge - os agentes que assumem a postura hedge avaliam que o risco é muito alto e por isso só tomam a decisão de investir se o valor do serviço da dívida, amortização acrescido de juros, for menor ou no máximo igual aos seus rendimentos futuros esperado.

ii) especulativo - os agentes que assumem a postura especulativa tomam a decisão de investir, baseado na expectativa de gerar um fluxo de caixa futuro maior do que o valor total da dívida. Sendo assim, eles tomam o empréstimo com a intenção de refinanciá-los no futuro. Por este motivo, esses agentes colocam como limite de seu endividamento a expectativa de que serão capazes de pagar pelo menos os juros da dívida para que a mesma não se amplie.

iii) ponzi - os agentes que assumem a postura ponzi, são aqueles que não possuem a expectativa de ter a capacidade de pagar, pelo menos em algum momento, nem a amortização nem os juros gerados pelo empréstimo. Por isso, esses agentes têm um fluxo de endividamento crescente durante determinado intervalo de tempo. Porém, é bom resaltar que a postura ponzi não é de inadimplência deliberada. Na realidade o agente acredita que os retornos do seu investimento só crescerão, e muito, em um prazo mais longo de tempo, mas não espera ficar inadimplente antes disto ocorrer, pois acredita que conseguira facilmente refinanciamento para as parcelas de amortização e juros iniciais, supondo que haverá elevada liquidez no mercado financeiro quando este momento chegar.

A teoria evolucionaria surge na Ciência Econômica, após a década de 70, em meio a um ambiente de estagnação e crise, com o interesse de fornecer respostas mais plausíveis aos problemas

Econ. e Desenv., Santa Maria, vol. 27, n.2, p. 276 - 296, jul. - dez. 2015 RE\&D 
econômicos, já que na visão dos economistas desta corrente de pensamento, a teoria convencional não era capaz de explicar de forma satisfatória os processos de mudanças que estavam ocorrendo no período e seu impacto para a economia (LEITE, 2011).

A principal referência do pensamento evolucionário, o trabalho de Nelson e Winter (1982) aborda a insuficiência metodológica da teoria neoclássica para as explicações dos fenômenos econômicos. Para teoria evolucionária a análise da economia deve ser feita a partir de pressupostos de desequilíbrios, no qual a incerteza faz parte do ambiente, sendo impossível prever perturbações que poderão afetar o objeto de estudo e por isso a instabilidade se torna inerente ao processo, enquanto que a teoria neoclássica busca teorizar o objeto de estudo através de uma análise estática, pressupondo equilíbrio a um sistema fechado no qual todas as perturbações que possam afetar esse sistema é totalmente ponderável, assim tornando o objeto da análise completamente previsível (LUZ; FRACALANZA, 2008).

Os ambientes de mercado oferecem uma definição de sucesso para as firmas, e essa definição está muito próxima à habilidade delas de sobreviver e crescer. Padrões diferenciais de sobrevivência e crescimento numa população de firmas podem produzir mudanças nos agregados econômicos que caracterizam aquela população, ainda que as características correspondentes das firmas individuais sejam constantes (NELSON; WINTER apud LUZ; FRACALANZA, 2008, p. 38).

A analogia entre os elementos retirados da teoria da biologia evolucionária e a teoria econômica não ortodoxa, foram fatores importantes trazidos no trabalho de Nelson e Winter (1982), que contribuíram para a introdução de argumentos evolucionários nas teorias econômicas. Esses autores enfatizam a necessidade da inovação como sendo um princípio dinâmico fundamental para uma mudança estrutural em um sistema. É esse conceito de inovação que os remetem a Schumpeter justificando o fato de tratar a abordagem como Evolucionária Neo-Schumpeteriana (LEITE, 2011).

De acordo com Silva (2004), as constantes mudanças na economia capitalista provocadas pela busca incessante da inovação, principalmente as inovações tecnológicas, provocam processos de transformações econômicas e institucionais. Essas transformações são resultado direto da interação de dois processos que podem ser comparados aos processos presentes na teoria da evolução das espécies:

i) a inovação seria a mutação genética, ressaltando que a mutação das empresas não é aleatória e sim proposital, embora elas não saibam, ex-ante, se conseguirão ou não inovar; mercado.

ii) o crivo pela qual essas inovações precisariam passar seria o processo de seleção de

O que se busca absorver de mais importante na teoria evolucionária é o conceito da inovação e seleção. A inovação proporcionará uma mudança de paradigma em um modelo precário (insuficiente) ou saturado, essa inovação passará por mecanismos de seleção colocando à prova a consistência do novo modelo que surge, sua capacidade de adaptação e evolução.

Outro conceito importante na teoria evolucionária esta relacionada ao que Nelson \& Winter denominaram de "regime tecnológico", conceito que remete à compreensão de que vários processos de evolução consistem em melhoramentos cumulativos, ou seja, processos que passaram por períodos de aperfeiçoamento ao longo do tempo (SILVA, 2004).

Um paradigma tecnológico pode ser compreendido como um direcionador do progresso técnico, ele separa os problemas manifestados nas inovações passadas baseado nas experiências anteriores, dos fatores benéficos. Sendo assim, em um processo evolutivo que esteja sendo aprimorado continuamente, o paradigma tecnológico direciona as oportunidades que devem ser perseguidas e as que devem ser abandonadas (LEITE, 2011).

O processo de mudança de paradigma é bastante complicado, isso porque um paradigma se constitui em uma forma duradoura de se executar algum tipo de procedimento. Por ter esse caráter

RE\&D Econ. e Desenv., Santa Maria, vol. 27, n.2, p. 276 - 296, jul. - dez. 2015 
duradouro é compreensível que ele passa a ser tratado como verdade única, ou utilizado, no caso de um procedimento, já que os indivíduos acabam se habituando. Desse modo a mudança de paradigma se caracteriza por ser um processo de aprendizagem, e deixar o 'velho' e se habituar ao 'novo' não é um processo tão trivial. Isso pode ocorrer de forma simples entre os jovens devido a rápida capacidade de absorção de novas ideias e a vasta curiosidade para se aprender novos procedimentos. Não é fácil percorrer caminhos desconhecidos após ter obtido êxito em locais já bem habituados (PÉREZ apud LEITE, 2011).

O conceito de paradigma tecnológico é de fundamental importância para analisar as inovações financeiras que provocaram grandes transformações nos mercados imobiliários. Juntas, a teoria evolucionária e a Hipótese da Fragilidade Financeira, se tornam um poderoso arcabouço teórico para explicar o processo de transformação nos modelos de financiamento.

\section{O MODELO DE FINANCIAMENTO HABITACIONAL BRASILEIRO: UMA RETROSPECTIVA}

O financiamento habitacional no Brasil começa a ter importância estratégica no início da década de 60, pois é durante este período que surge o Sistema Financeiro da Habitação (SFH).

$\mathrm{O}$ problema habitacional brasileiro é contemporâneo ao século XX, momento em que ocorreu o desenvolvimento manufatureiro-industrial no país. Quando se iniciou o processo de concentração de indústrias nos grandes centros urbanos, a população que residia na zona rural e em pequenas cidades começou a migrar para os grandes centros na busca por emprego. Devido à alta demanda por mão de obra, mas com baixíssima remuneração e na ausência de políticas públicas, houve um grande crescimento populacional de maneira desorganizada nas grandes cidades (FGV, 2007).

A questão habitacional no Brasil era de total responsabilidade do setor privado até 1930, em outras palavras, não existiam políticas direcionadas para tentar resolver o problema do déficit habitacional. Só após a década de 30, com o início das políticas públicas que caracterizaram o 'varguismo' e devido ao processo de industrialização e todo o problema da habitação irregular trazido com ele, o governo brasileiro toma as primeiras medidas para tentar solucionar o problema da moradia popular, passando a construir os primeiros conjuntos habitacionais.

Com relação ao financiamento privado, entre os anos de 1956 a 1961, período de grande expansão e transformação produtiva (motivadas pelos investimentos do Plano de Metas), o Brasil estava vivendo um período de aumento gradativo dos preços e, em razão disso, os setores de crédito direcionado para o financiamento imobiliário estavam tendo grandes prejuízos devido à ausência de correção monetária para os contratos. Sendo assim, os recursos disponíveis para financiamento imobiliário foram ficando cada vez mais escassos. Com a falta de crédito, a alternativa que existia era estender o período de construção dos imóveis, pois os demandantes, pessoas interessadas em comprar um imóvel, enfrentavam dificuldades na obtenção de crédito, assim como os empreendedores tinham dificuldade de captar recursos para financiar os altos custos do empreendimento. Deste modo, com o prolongamento do período de conclusão das obras os imóveis se tornavam cada vez mais onerosos e desinteressantes (Moraes, 2008).

O prolongamento no tempo de construção dos imóveis reflete uma postura defensiva "hedge" adotada pelos construtores, pois, o ambiente de baixa liquidez sugere spreads cada vez maiores e a decisão do tomador de crédito em momentos como este passará pela avaliação da sua capacidade de conseguir pagar a amortização acrescida de juros. Essa situação deixava os construtores bastante receosos com relação ao cenário futuro, restando uma segunda alternativa que era financiar as obras a partir de recursos próprios.

No caso do financiamento bancário, o fator que gerava maior impedimento era que as taxas de juros pagas pelos bancos para remunerar os investidores eram nominais constantes. Com a aceleração

Econ. e Desenv., Santa Maria, vol. 27, n.2, p. 276 - 296, jul. - dez. 2015 RE\&D 
da inflação, essas taxas passaram a ser negativas, fato que gerou total desinteresse por parte dos fundos de investimentos e de investidores individuais de aplicarem seus recursos no setor de crédito imobiliário (FGV, 2007).

(RUDGE; AMENDOLARA apud VEDROSSI, 2002), reforçam o argumento acima apresentado acrescentando que a escassez de crédito para esse tipo de financiamento também se devia ao fato de que a inflação brasileira anual, naquele período, geralmente ultrapassava os $12 \%$ a.a1 e limitava os juros nominais a $12 \%$ a.a, desse modo à inflação corroia toda a remuneração auferida pela taxa de juros, o que provocava o total desinteresse dos investidores em atuarem neste mercado. Vale ressaltar que os créditos que ainda estavam disponíveis eram altamente subsidiados.

Até o ano de 1964, o financiamento habitacional era algo bastante restrito devido à ausência de dois fatores que são fundamentais para o bom funcionamento de um mercado de crédito imobiliário. O primeiro era com relação aos mecanismos que preservassem os valores reais dos empréstimos, considerando o longo prazo que é necessário para a liquidação desse tipo de financiamento (correção monetária dos contratos). O outro problema era com relação à necessidade de um arcabouço jurídico e institucional para padronizar os contratos trazendo mais segurança aos investidores, além de criar mecanismos de financiamento estruturado para articular a demanda e a oferta.

Devido à ausência desses fatores, os poucos financiamentos que existiam naquela época eram realizados apenas pela Caixa Econômica Federal (CEF) e pelos Institutos de previdência segmentados por categorias profissionais. Por estes motivos, era bastante burocrática e restrita a obtenção de crédito junto a uma dessas instituições, de modo que na grande maioria dos casos, apenas pessoas que recebiam altos salários ou possuíam algum. patrimônio que pudesse ser dado como garantia real do empréstimo, conseguiam ter acesso a estes recursos (VEDROSSI, 2002).

Devido a grande dificuldade de se captar recursos para fomentar o mercado de crédito imobiliário frente às necessidades de promover rapidamente maiores investimentos habitacionais, o Governo Federal em 1964 criou a lei n ${ }^{\circ} 4.380$ que deu origem ao Sistema Financeiro da Habitação (SFH).

O SFH foi o grande avanço no âmbito das reformas bancárias e do mercado de capitais da época, proporcionando um ambiente favorável à captação de recursos para a habitação. O seu papel principal era de criar condições que facilitassem a construção e a aquisição da casa própria, com o foco direcionado principalmente à população de baixa renda (GOVERNO FEDERAL, 1964).

A lei $n^{\circ} 4.380$ instituiu uma série de órgãos e instituições, com interesse de promover a criação de um sistema capaz de resolver o problema habitacional. Ela institui a correção monetária nos contratos imobiliários de interesse social e o sistema financeiro para aquisição da casa própria. Além disso, a mesma criou o Banco Nacional da Habitação (BNH), as sociedades de crédito imobiliário, as letras imobiliárias e o Serviço Federal de Habitação e Urbanismo (SFHU) (GOVERNO FEDERAL, 1964). A introdução da correção monetária para os contratos imobiliários e a criação do BNH foram, sem dúvida, as grandes inovações institucionais trazidas pelo SFH, pois deu origem:

i) a um novo 'paradigma tecno-financeiro', ou seja, um novo 'padrão de solução' para os problemas específicos do sistema financeiro da habitação (a indexação), gerando uma nova trajetória tecno-financeira que permitiu a criação de uma sequência de novos produtos (contratos indexados à inflação) e respectivos mercados financeiros (com novos atores ofertantes e demandantes):

ii) um novo e poderoso ator no mercado bancário, o qual possuía poderes para agir como um market-maker, ou seja, capaz de afetar a dinâmica do mercado (preços, prazos, quantidades, qualidade, ofertantes e demandantes em diversos outros mercados).

iii) Uma nova estrutura jurídico-legal-regulatória.

\footnotetext{
${ }^{1}$ Lei $\mathrm{N}^{\mathrm{o}} 1.521$, de 26 de dezembro de 1951. Essa lei foi criada para proteger a economia popular contra crimes financeiros.
}

RE\&D Econ. e Desenv., Santa Maria, vol. 27, n.2, p. 276 - 296, jul. - dez. 2015 
Por atuar como um 'emprestador de última instância' do SFH, garantindo a liquidez e a solvência do sistema, ficou sob a responsabilidade do BNH gerir o Fundo de Garantia de Depósitos e Letras Imobiliárias (FGDLI). Este fundo tinha a função de garantir a integridade das poupanças populares aplicadas em letras imobiliárias e em caderneta de poupança. O FGDLI e o Fundo de Assistência de Liquidez (FAL), que era outro fundo que tinha o dever de prestar socorro em caso de falta de liquidez das entidades que compunham o Sistema Brasileiro de Poupança e Empréstimo (SBPE), deveriam juntos cobrir os eventuais riscos existentes nas atividades e operações do SFH. O FGDLI e o FAL captavam recursos através de contribuições compulsórias de um percentual dos saldos de recursos oriundos de instituições financeiras (MORAES, 2008). Sendo assim, o FGDLI e o FAL acabavam transformando operações que seriam avaliadas como especulativas ou ponzi em operações hedge, reduzindo a percepção geral de risco e incentivando os investimentos.

O SFH realizava a concessão de crédito a partir de fontes de recursos próprios. A capitalização desses recursos se dava principalmente através de duas fontes: a caderneta de poupança e o Fundo de Garantia por Tempo de Serviço (FGTS). A caderneta de poupança surgiu para incentivar as famílias a pouparem, portanto, ela é uma fonte de captação de recursos voluntária que obedece a um critério de exigibilidade, ou seja, uma parte é destinada ao investimento imobiliário. O FGTS atua como uma fonte de captação de recurso compulsório, já que é descontado, compulsoriamente, em folha um percentual do salário de cada trabalhador. A arrecadação desse recurso era utilizada na concessão do crédito para financiamento imobiliário além de direcionar uma parte dele para realizar obras de saneamento básico e infraestrutura urbana (FGV, 2007). (MCM CONSULTORES ASSOCIADOS apud VEDROSSI, 2002), complementa que em 1966 o FGTS, que era uma das fontes de captação de recursos do SFH, tornou-se o maior fundo institucional de poupança e capitalização e seus lucros direcionados e administrados pelo BNH. Isso contribuiu para ter um sistema mais líquido e com maior capacidade de geração e disponibilização de crédito.

Outra fonte de captação de recursos do SFH era através das letras imobiliárias que poderiam ser emitidas tanto pelas Sociedades de Crédito Imobiliário quanto pelo BNH. As letras imobiliárias são títulos que garantem uma promessa de pagamento futuro. Quando estas eram emitidas pelo BNH elas eram garantidas pela União Federal o que as tornava bastante seguras. Porém, o volume de recurso proveniente dessa fonte era bastante reduzido em razão da própria conjuntura econômica da época, problemas inflacionários, baixos salários da maior parte da população, além de o Brasil, naquela época, não possuir um mercado secundário líquido suficientemente desenvolvido para um nível de comercialização desses títulos que pudesse capitalizar grandes volumes de recursos para o $\mathrm{SFH}$.

O FGTS, as cadernetas de poupanças e os serviços de intermediação financeira eram remunerados pelos juros provenientes dos empréstimos, que no novo modelo poderia ser realizado por um período de até 30 anos, fato este que marca um avanço em relação ao arranjo anterior.

\section{1 - INOVAÇÕES NO SISTEMA FINANCEIRO DE HABITAÇÃO}

Já nos primeiros anos em que o SFH foi instituído, começaram a surgir os primeiros problemas. Esse fato colocou à prova a capacidade de inovação que o sistema teria que ter para se adaptar as novas exigências que surgiam. Isso porque apesar de ter sido criado um ambiente mais favorável ao desenvolvimento do financiamento habitacional, já no princípio, havia um descontentamento dos mutuários com relação aos reajustes realizados para corrigir os valores dos empréstimos, pois as correções monetárias das prestações ocorriam em descompasso com as correções salariais. Dessa forma, caso houvesse um saldo residual ao final do período do financiamento, este deveria ser pago pelos mutuários, conforme previa a legislação.

Econ. e Desenv., Santa Maria, vol. 27, n.2, p. 276 - 296, jul. - dez. 2015 RE\&D 
Em 1967 foi criado o Fundo de Compensação de Variações Salariais (FCVS), uma inovação bastante importante introduzida no sistema, que permitia que os reajustes no valor das prestações entrassem em compasso com os reajustes do salário mínimo e a diferença entre essa variação e a variação real da inflação pudesse ser coberta pelo FCVS respeitando as regras vigentes. O fundo era capitalizado através de uma sobre taxa que foi aplicada nas prestações dos financiamentos. A criação do fundo acabou com o descontentamento de alguns tomadores de crédito que viam os valores das parcelas dos seus financiamentos aumentarem desproporcionalmente com relação aos seus salários (VEDROSSI, 2002)

Em 1969 foi introduzido o Coeficiente de Equiparação Salarial (CES). Este coeficiente era responsável por solver os resíduos originados entre o reajuste das prestações (anuais) e dos saldos devedores (trimestrais). Para as famílias de baixa renda ainda havia a vantagem do subsídio cruzado, outra inovação importante do SFH, que cobrava taxas de juros progressivas de acordo com o valor do financiamento (FGV, 2007).

Como mostra o gráfico (1), tais inovações promoveram um grande desenvolvimento do sistema, entre 1966 e 1969, período iniciado com a implantação do FCVS, a partir de então é possível verificar o grande aumento no número de unidades habitacionais financiadas. Em 1980 o SFH alcançou seu auge chegando a financiar mais de 600 mil unidades habitacionais no ano, o que significava na época $70 \%$ dos domicílios construídos no país.

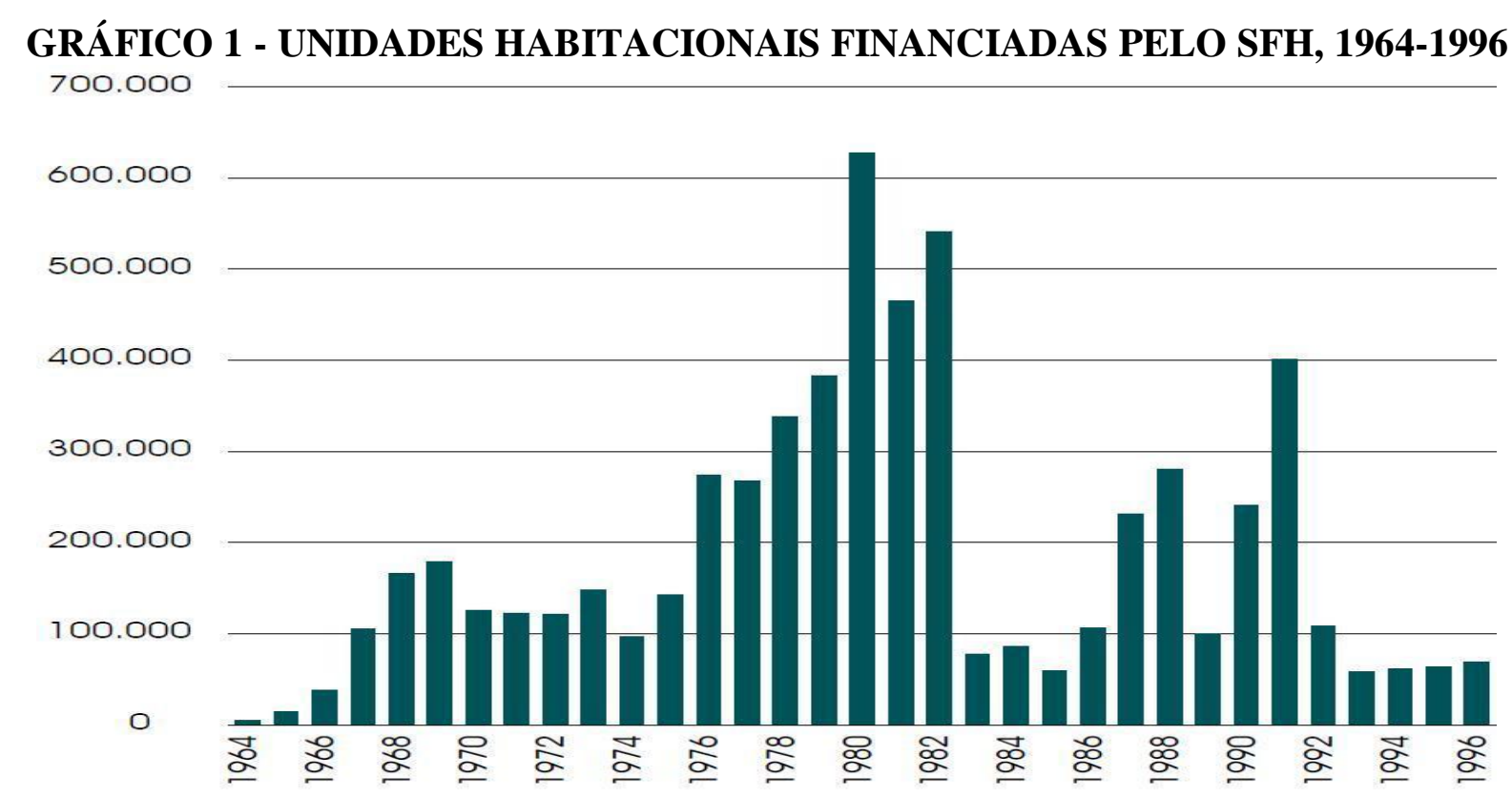

Fonte: FGV (2007)

Porém, com os problemas econômicos que surgiram na década de 80, como, por exemplo, a crise da dívida externa entre os anos de 81 e 83, elevação da inflação e redução dos salários reais, o sistema perdeu seu dinamismo. Os recursos disponíveis para os financiamentos foram diminuindo e a elevação nas taxas de juros provocou desequilíbrio nas carteiras dos agentes financeiros. O FCVS foi bastante onerado, devido a uma série de benefícios concedidos pelo governo em resposta ao aumento do índice de inadimplência dos mutuários que, devido ao arrocho salarial, não estavam tendo condições de pagar o financiamento (MORAES, 2008).

RE\&D Econ. e Desenv., Santa Maria, vol. 27, n.2, p. 276 - 296, jul. - dez. 2015 


\subsection{O ESGOTAMENTO DO SISTEMA FINANCEIRO DE HABITAÇÃO}

Os fatores que provocaram o esgotamento do SFH estão relacionados aos problemas que são inerentes ao próprio sistema e problemas externos oriundos da conjuntura econômica que estava sendo desenhada na época. Esses fatores foram abordados de maneira muito clara no trabalho de Brollo (2004) baseado nos trabalhos de Rabelo (1997) e Castelo (1997), que demonstrou o quanto que o SFH na época era vulnerável e necessitava de um ambiente econômico favorável para o seu pleno funcionamento, a seguir são elencados os principais fatores baseados no argumento feito por Brollo (2004):

i)A falta de comunicação entre o sistema e os demais segmentos do mercado: essa falta de conexão provoca uma incapacidade de captação de recursos através de outros instrumentos financeiros; ii) A instabilidade congênita do sistema, provocado pelos prazos de permanência incertos dos depósitos nos fundos que são destinados ao financiamento imobiliário: só um ambiente econômico favorável poderia proporcionar uma expansão em um sistema como o SFH, que capta recursos no curto e médio prazo e empresta-os no longo prazo.

Segundo Moraes (2008), em 1983 o princípio da identidade de índice foi quebrado, pois, com a ameaça ao sistema, devido às reduções salariais e o aumento da inadimplência, neste mesmo ano o governo aplicou às prestações um reajuste de $80 \%$ em relação ao reajuste dado ao salário mínimo, de modo que se o salário foi reajustado em 100 , às parcelas seriam reajustadas em 80 , gerando assim um subsídio automático aos mutuários. No ano de 1984, devido à aceleração inflacionária, esse subsídio foi novamente dado pelo governo, porém, de forma indiscriminada, sendo concedido diretamente como o caso anterior ou indiretamente como reflexo dos vários planos econômicos.

Os subdimensionamento dos reajustes das prestações permaneceram durante o ano de 1985 e neste ano ainda houve o bônus do SFH. Este bônus funcionava da seguinte forma, os mutuários deveriam aceitar os reajustes semestrais e em contrapartida o reajuste da prestação seria de $112 \%$ indo contra a inflação do ano anterior registrada em $243 \%$. Todo o ônus causado por esses subsídios dados aos mutuários foi absorvido pelo FCVS, além de que a parcela mais beneficiada por estes subsídios era formada pela parte da população que possuíam plenas condições de se autofinanciarem. Esses fatores comprometeram a disponibilização de recursos para as gerações futuras e proporcionaram a geração de um passivo potencial de proporções bilionárias para o FCVS (IPEA, 1996).

Ainda com relação à diminuição dos recursos destinados a promover o financiamento habitacional, com o Plano Cruzado, foram incluídos no congelamento de preços o FGTS, os saldos devedores dos financiamentos e as cadernetas de poupança. Apesar de ter voltado a receber reajuste trimestral e de ser o único ativo financeiro com prazo de correção inferior a um ano, houve neste período o registro de captação negativa. Isto se justificou em primeiro lugar devido ao aumento do consumo de bens duráveis, fato que provocou uma retirada expressiva de recursos aplicados na caderneta de poupança. Um segundo motivo foi o aumento dos depósitos compulsórios no Banco Central sobre os saldos, fato que gerou um esvaziamento ainda maior dos recursos que eram destinados ao SFH (BROLLO, 2004).

No quadro a seguir, são detalhados em ordem cronológica os fatores responsáveis pela onerosa dívida gerada para o FCVS compreendendo o período de 1977 a 1991.

Econ. e Desenv., Santa Maria, vol. 27, n.2, p. 276 - 296, jul. - dez. 2015 RE\&D 
QUADRO 1 - FATORES RESPONSÁVEIS PELO PASSIVO GERADO NO FCVS

\begin{tabular}{|c|l|}
\hline \multicolumn{1}{|c|}{ ANO } & \multicolumn{1}{c|}{ Fatores que oneraram o FCVS } \\
\hline 1977 & $\begin{array}{l}\text { Subdimensionamento do Coeficiente de Equiparação Salarial (CES). Esse coeficiente tinha por } \\
\text { objetivo compatibilizar a correção trimestral dos saldos com o reajuste anual dos encargos para um } \\
\text { determinado nível de inflação. }\end{array}$ \\
\hline 1973 a 1982 & $\begin{array}{l}\text { Substituição do salário mínimo como indexador das prestações pelo salário mínimo habitacional e, } \\
\text { posteriormente, pela UPC. Como os reajustes foram, de um modo geral, superiores à variação da } \\
\text { correção monetária no período em questão, impediu-se, na prática, que essa diferença fosse } \\
\text { incorporadas às prestações. }\end{array}$ \\
\hline 1983 e 1984 & $\begin{array}{l}\text { Sub-reajustamento das prestações pela aplicação de índice correspondente a 80\% da variação do } \\
\text { salário mínimo }\end{array}$ \\
\hline 1985 & $\begin{array}{l}\text { Sub-reajustamento das prestações de índice correspondente a 112\% contra os 246\% aplicados aos } \\
\text { saldos devedores dos financiamentos. }\end{array}$ \\
\hline 1986 & $\begin{array}{l}\text { Plano Cruzado - conversão do valor das prestações pela média de até 12 meses anteriores, seguida } \\
\text { de congelamento para os 12 meses seguintes. }\end{array}$ \\
\hline 1987 & $\begin{array}{l}\text { Plano Bresser - congelamento temporário e adoção de nova política salarial através da Unidade } \\
\text { Referencial de Preços (URP), com consequências negativas sobre a evolução das prestações. }\end{array}$ \\
\hline 1989 & $\begin{array}{l}\text { Plano Verão - novo congelamento das prestações, no período de fevereiro a maio, sem o repasse } \\
\text { para as prestações das URP recebidas nos salários em dezembro de 1988 e janeiro de 1989. }\end{array}$ \\
\hline 1990 & $\begin{array}{l}\text { Plano Collor I - correção dos saldos devedores com base no IPC de 84,32\%, índice este que não } \\
\text { foi repassado para as prestações com reajustes vinculados ao Plano de Equivalência Salarial } .\end{array}$ \\
\hline 1991 & $\begin{array}{l}\text { Plano Collor II - inexistência de política salarial oficial até setembro impossibilitou o repasse de } \\
\text { antecipações salariais para as prestações entre maio e outubro. }\end{array}$ \\
\hline
\end{tabular}

Fonte: Moraes (2008)

Devido à má gestão e os sérios problemas pelo qual SFH estava passando, a partir do decretolei 2.291 de 21 de agosto de 1986, o BNH foi extinto e suas funções foram distribuídas entre os seguintes órgãos do governo: a Caixa Econômica Federal (CEF), o Ministério do Desenvolvimento Urbano e Meio Ambiente (MDU), o Conselho Monetário Nacional (CMN) e o Banco Central do Brasil (BC). Essa reorganização dos atores do sistema marca um período de inovação na governança. A extinção do BNH e a reorganização de suas funções se configuraram em inovações institucionais.

A CEF ficou responsável por suceder o BNH em todos os seus direitos e obrigações, inclusive na administração dos ativo e passivo, assim como do pessoal e dos bens móveis e imóveis, além da gestão do FGTS, do Fundo de Assistência Habitacional e do Fundo de Apoio à Produção de Habitação para a População de Baixa Renda. Também passou a ser de responsabilidade da CEF a coordenação e execução do Plano Nacional de Habitação Popular (PLANHAP) e do Plano Nacional de Saneamento Básico (PLANASA). Ao MDU coube a tarefa de formular propostas de política habitacional e de desenvolvimento urbano. O BC ficou com o dever de fiscalizar as entidades integrantes do SFH e a aplicação das penalidades previstas. Coube ao CMN o papel de órgão central do sistema, com o dever de orientar, disciplinar e fiscalizar o SFH.

Em 1964, todas as operações do sistema eram realizadas pela Carteira de Operações Sociais (COS) do BNH. Em apenas cinco anos essas operações caíram para menos de $40 \%$ de todas as operações do sistema, chegando a seus piores níveis entre os anos de 1970 a 1974, quando a COS operou uma média de $12 \%$ com relação a todas as operações realizadas. Considerando que o auge do SFH foi no ano de 1980, até esse período o atendimento a população pobre foi reduzida, atingindo um pouco mais de $30 \%$ da cobertura com relação ao total do sistema. No gráfico (2) a seguir é demonstrada claramente a incapacidade do sistema de atendimento a classe pobre da população.

RE\&D Econ. e Desenv., Santa Maria, vol. 27, n.2, p. 276 - 296, jul. - dez. 2015 


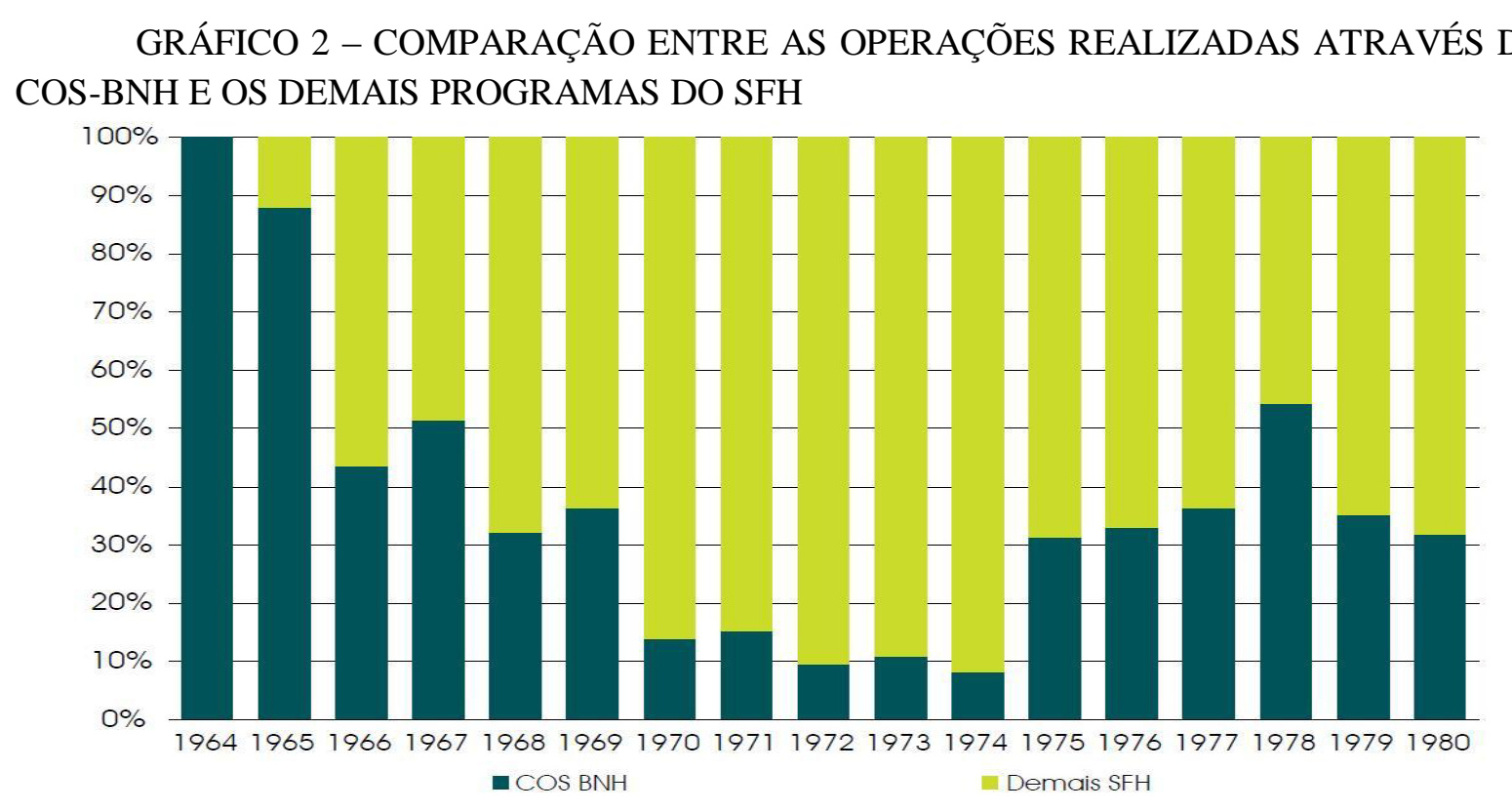

Fonte: FGV (2007)

Após a sua primeira grave crise, que compreende o período entre 1983 a 1985, o sistema começa a retomar um crescimento bastante modesto entre os anos de 1986 a 1988, porém, já em 1989, o sistema retoma níveis de financiamento correspondentes a 100 mil unidades anuais. Ele retoma no ano seguinte uma nova fase de crescimento, que pela segunda vez dura apenas 2 anos que é justamente nos anos de 1990 e 1991. Em 1992 ele retorna aos seus baixos níveis de financiamento e por lá se mantém até o ano de 1996.

Vale a pena ressaltar, que no período que compreende os anos de 1993 a 1996 a quantidade de unidades residenciais financiadas pelo sistema foi menor do que em sua primeira crise. Toda essa trajetória de recuperação dos níveis de financiamento e declínio mencionado pode ser acompanhada no gráfico (1) já apresentado no começo da seção.

Essa grande instabilidade do SFH entre os anos anteriormente mencionados, na qual em alguns períodos eram registrados um aumento na quantidade de unidade habitacional coberta pelo financiamento e em outros períodos uma redução do nível de financiamento, pode ser compreendida pela grande vulnerabilidade do sistema aos ambientes econômicos. Como nesse período o país passou por graves situações, como altas taxas de juros e a inflação crescente, esses fatores provocavam um impacto negativo no sistema, consequentemente, sempre que se implantavam novos pacotes econômicos que promoviam uma breve estabilização econômica, o sistema voltava a crescer.

Fazendo um balanço geral de tudo o que ocorreu entre o período de implantação do SFH em 1964 até a década de 90, é possível afirmar que o Brasil mais perdeu do que ganhou, essa afirmação tem por base dois fatores: (i) o primeiro é devido ao fato de que o SFH não foi capaz de realizar o seu principal objetivo, que era promover a habitação para a classe mais pobre da população, (ii) o segundo motivo foi a grande herança negativa herdada pelo país através do rombo bilionário do FCVS.

Embora o SFH tenha representado naquele período um avanço com relação a um modelo de financiamento imobiliário, introduzindo inovações e evoluindo durante o seu tempo de existência, esse sistema não foi capaz de superar o caos inflacionário e o desequilíbrio institucional.

Econ. e Desenv., Santa Maria, vol. 27, n.2, p. 276 - 296, jul. - dez. 2015 RE\&D 


\section{A SITUAÇÃO DO FINANCIAMENTO IMOBILIÁRIO BRASILEIRO NA ÚLTIMA DÉCADA}

O Brasil inicia o novo século sem grandes propostas para promover o crescimento do setor imobiliário. A última tentativa de se criar um novo modelo e, assim, proporcionar uma expansão no setor ocorreu em 1997 com a criação do SFI. Porém, graves crises externas e problemas econômicos internos, altas taxas de juros, baixo nível de crescimento, entre outros fatores, acabaram deixando evidente que o mercado secundário líquido, que seria necessário existir para promover o bom desempenho do novo sistema, não conseguiu se desenvolver, pelo contrário, como já foi mostrado no capítulo anterior, o SFI não conseguiu obter êxito em seu propósito. Entre os anos de 1997 a 2002 a quantidade de financiamento realizado pelo sistema ficou bem inferior aos financiamentos realizados pelo SFH.

Foi criado, em 2003, o Ministério das Cidades através da medida provisória ${ }^{\circ} 103$ que depois foi convertida na Lei ${ }^{\circ} 10.683$. Uma das funções do ministério era elaborar, acompanhar e avaliar os instrumentos necessários para a implementação da Política Nacional da Habitação (PNH). Com a aprovação do PNH em 2004, houve uma ampliação da visão e integração das questões de desenvolvimento urbano nas cidades.

Em 2007 é lançado o Programa de Aceleração do Crescimento (PAC). O PAC foi implantado na segunda gestão do governo Luiz Inácio Lula da Silva com intuito de promover a retomada das grandes obras de infraestrutura urbana, social, logística e energética do país. Assim, a maior parcela dos recursos era repassada para promover a expansão e desenvolvimento habitacional.

Devido à crise econômica mundial de 2008, que provocou a desaceleração das principais economias do mundo, no ano seguinte o governo brasileiro injetou $\mathrm{R} \$ 41,8$ bilhões no programa. Essa medida visava evitar que a crise impactasse o ritmo de crescimento brasileiro. Do total de recursos aplicados no PAC em 2009, 83,9\% foi direcionado para o setor de habitação. Esse percentual representa um volume de mais de $\mathrm{R} \$ 35$ bilhões de investimento.

Os investimentos no PAC realizados como medida anticíclica de combate à crise econômica mundial proporcionou mais espaço dentro do sistema. A CEF que antes operava principalmente através das aplicações da poupança e do FGTS obteve com o PAC mais recursos tanto para promoção de projetos ligados à habitação social, quanto para disponibilização de crédito para o financiamento de imóveis.

\section{GRÁFICO 3 - DISTRIBUIÇÃO DA META DO PAC PARA CONSTRUÇÃo DE UNIDADES HABITACIONAIS POR REGIÃO}

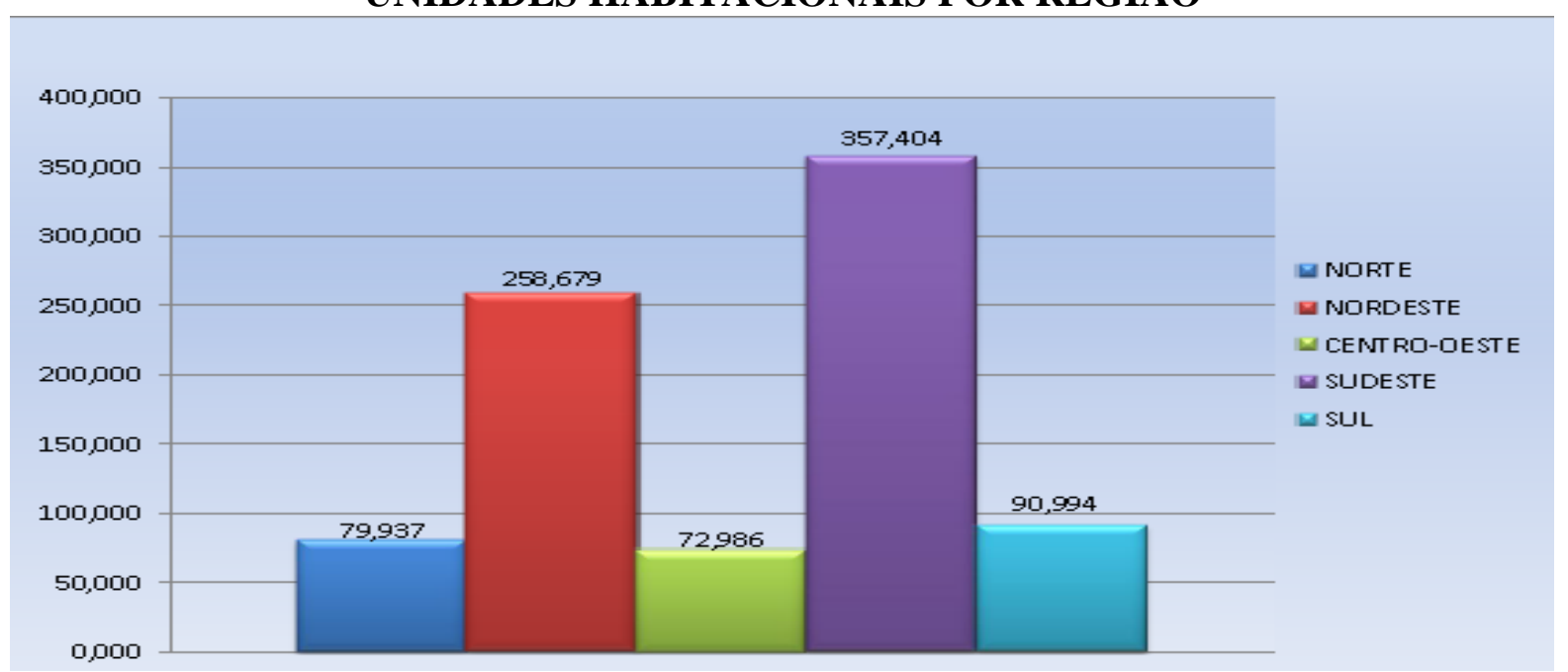

Fonte: Elaboração própria a partir dos dados da portaria № 465 do Ministério das Cidades, 2011

RE\&D Econ. e Desenv., Santa Maria, vol. 27, n.2, p. 276 - 296, jul. - dez. 2015 
Dando continuidade às medidas anticíclicas para manter o crescimento do país frente à grave crise internacional, o governo utilizou o setor habitacional como alvo prioritário na política de geração de empregos e crescimento econômico. Em 2009 foi criado o Programa Minha Casa Minha Vida (PMCMV), outro grande incentivo que junto ao PAC se constituiu nos principais fatores que determinaram a grande expansão imobiliária observada nos últimos anos.

O público alvo do programa é a parcela da população que tem uma renda familiar mensal de até R $\$ 1.600,00$. Para estes, o programa projetou uma meta de produção de 860.000 unidades habitacionais até 2014. Essas operações serão realizadas a partir de recursos do Fundo de Arrendamento Residencial (FAR), exclusivo para esta faixa de renda. O gráfico 3 mostra a meta de construção de residências por regiões,

De acordo com a estimativa do déficit habitacional urbano, considerando os dados da Pesquisa Nacional por Amostra de Domicílios (PNAD) e do Instituto Brasileiro de Geografia e Estatística (IBGE) para o ano de 2008, para as famílias que recebem uma renda mensal de até $\mathrm{R} \$ 1.600,00$, serão utilizados na viabilização das obras, recursos aportados ao FAR transferidos do Orçamento Geral da União (OGU). Este orçamento é distribuído pelas 27 Unidades Federativas, de acordo com a meta física de unidades habitacionais por unidades da federação.

Entre 2001 e 2009 o Brasil saiu de um total de 46.994.866 domicílios para 58.646.432, em 8 anos foram construídos mais de 11 milhões de novas residências, representando um crescimento de $24,79 \%$.

As regiões que tiveram as maiores participações neste crescimento foram o Sudeste e o Nordeste, o peso de suas participações no total foram $37,65 \%$ e $26,75 \%$ respectivamente. A região Sudeste tinha em 2001 um total de 21.358.282 unidades habitacionais, em 2009 esse número passou a ser de 25.745.170, enquanto que no Nordeste no mesmo período o número de residências saiu de 12.238.610 para 15.355.584. Apenas nestas duas regiões foram construídos em 8 anos mais de 7 milhões de novas unidades residenciais. Na figura abaixo é mostrado como ficou a participação de cada região na ampliação do número de unidades residenciais construídas no período. (Ver Figura 1)

\section{FIGURA 1 - PESO DAS REGIÕES NO CRESCIMENTO HABITACIONAL}

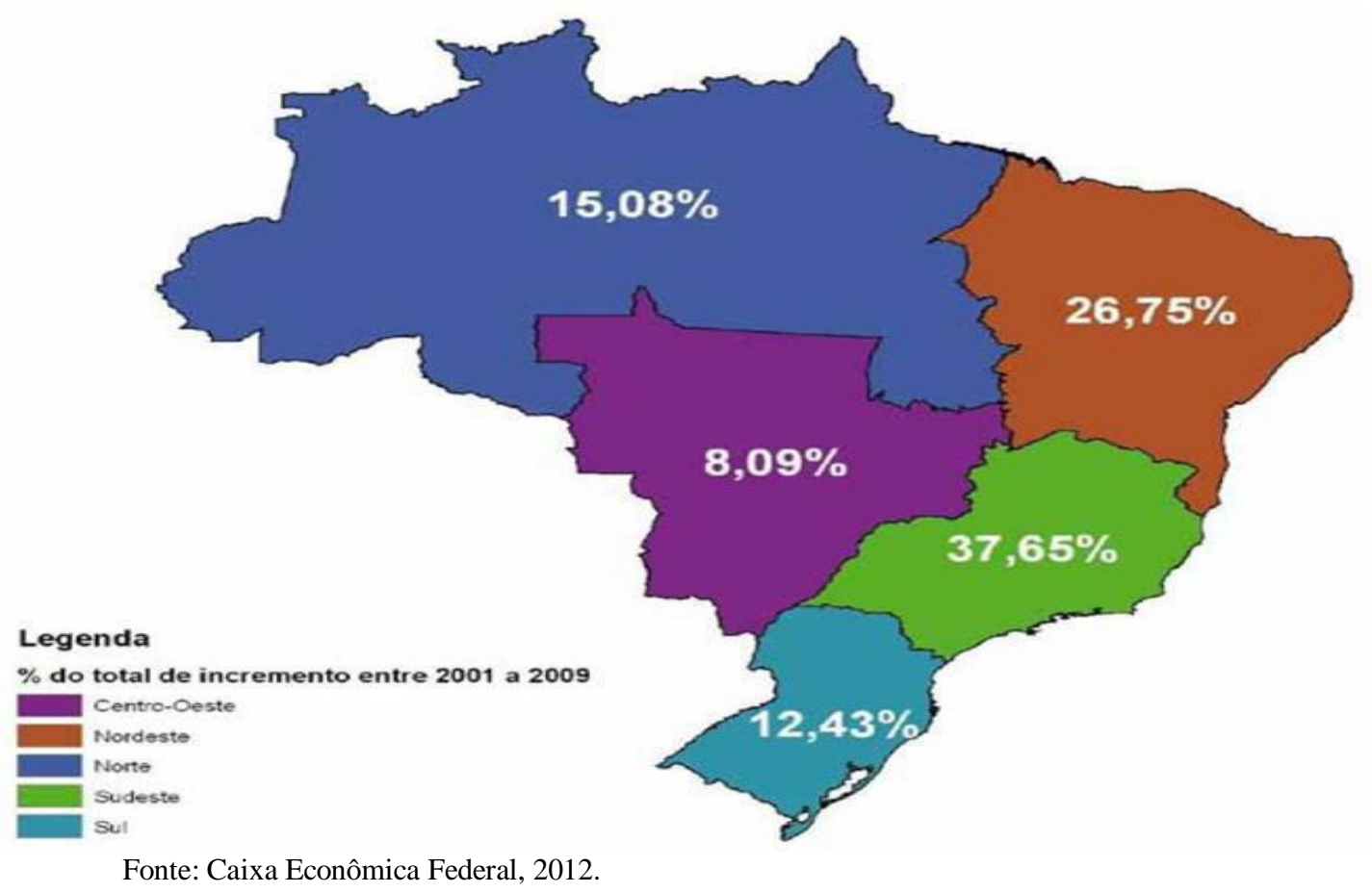

Econ. e Desenv., Santa Maria, vol. 27, n.2, p. 276 - 296, jul. - dez. 2015 RE\&D 
Em termos de variação o Norte foi à região que mais cresceu proporcionalmente, ela ampliou em $74,31 \%$ a quantidade de unidade habitacional, enquanto que as outras regiões mantiveram uma média de crescimento em torno de $23,15 \%$. Em termos absolutos, o gráfico a seguir mostra com maior clareza o aumento do numero de habitação por cada região, tendo um destaque maior para o crescimento no Sudeste e no Nordeste como já havia sido mencionado anteriormente.

TABELA 2 - DISTRIBUIÇÃO DA META DO PAC PARA CONSTRUÇÃO DE UNIDADES HABITACIONAIS POR REGIÕES DO BRASIL

\begin{tabular}{|l|l|l|l|l|l|l|}
\hline ANO & BRASIL & Sul & Sudeste & Centro-Oeste & Nordeste & Norte \\
\hline 2001 & 46.994 .866 & 7.618 .621 & 21.358 .282 & 3.414 .492 & 12.238 .610 & 2.364 .861 \\
\hline 2002 & 48.095 .210 & 7.793 .572 & 21.885 .825 & 3.513 .240 & 12.457 .726 & 2.444 .847 \\
\hline 2003 & 49.729 .167 & 7.993 .865 & 22.561 .831 & $3,665.155$ & 12.932 .760 & 2.575 .556 \\
\hline 2004 & 51.666 .039 & 8.162 .928 & 22.935 .084 & 3.771 .164 & 13.263 .879 & 3.532 .984 \\
\hline 2005 & 52.910 .174 & 8.327 .947 & 23.497 .336 & 3.871 .438 & 13.542 .575 & 3.670 .878 \\
\hline 2006 & 54.282 .533 & 8.467 .844 & 24.129 .438 & 3.980 .904 & 13.989 .626 & 3.714 .721 \\
\hline 2007 & 55.877 .855 & 8.768 .147 & 24.660 .563 & 4.172 .740 & 14.444 .825 & 3.831 .580 \\
\hline 2008 & 57.656 .117 & 9.004 .353 & 25.341 .417 & 4.264 .492 & 15.010 .978 & 4.034 .877 \\
\hline 2009 & 58.646 .432 & 9.066 .510 & 25.745 .170 & 4.356 .883 & 15.355 .584 & 4.122 .285 \\
\hline
\end{tabular}

Fonte: Elaboração própria a partir dos dados da Caixa Econômica Federal, 2012.

Segundo a CEF (2012), foi constatado que houve uma redução na demanda por habitação comparada ao número de domicílios existentes no Brasil entre os anos de 2001 a 2009. Esse resultado foi obtido através da análise de dados do censo de 2000 do IBGE e dos dados da série histórica da PNAD para o mesmo período. Através dessas duas fontes de dados, foram extraídos a Demanda Habitacional Demográfica (DHDE) e a Demanda Habitacional Domiciliar (DHDO), estratificadas por faixa de renda para o Brasil e para as Unidades da Federação. A Demanda Habitacional total se constitui da soma das outras duas demandas (DHT = DHDE + DHDO) 2 .

Ao analisar a demanda total com relação à quantidade de domicílios, ficou constatado que houve uma redução de 3,91 pontos percentuais, a demanda com relação a quantidade de imóveis existentes que era de $19,76 \%$ em 2001 passa a ser $15,85 \%$ no ano de 2009 . Estes valores estão ilustrados na tabela (3).

TABELA 3 - DEMANDA POTENCIAL

\begin{tabular}{|c|c|c|c|c|c|}
\hline ANO & $\begin{array}{c}\text { QUANTIDADE } \\
\text { DE } \\
\text { DOMICÍLIOS }\end{array}$ & $\begin{array}{c}\text { DHDE } \\
\text { DEMANDA } \\
\text { DEMOGRAFICA }\end{array}$ & $\begin{array}{c}\text { DHDO } \\
\text { DEMANDA } \\
\text { DOMICILIAR }\end{array}$ & $\begin{array}{c}\text { DHT DEMANDA } \\
\text { TOTAL } \\
\text { (DHDE+DHDO) }\end{array}$ & $\begin{array}{c}\text { DHT DEMANDA } \\
\text { TOTAL\% }\end{array}$ \\
\hline 2001 & 46.994 .866 & 5.441 .662 & 3.845 .659 & 9.287 .321 & $19,76 \%$ \\
\hline 2002 & 48.095 .210 & 5.562 .830 & 3.498 .303 & 9.061 .133 & $18,84 \%$ \\
\hline 2003 & 49.729 .167 & 5.746 .217 & 3.247 .523 & 8.993 .740 & $18,09 \%$ \\
\hline 2004 & 51.666 .039 & 6.043 .317 & 3.151 .322 & 9.194 .639 & $17,80 \%$ \\
\hline 2005 & 52.910 .174 & 6.199 .923 & 3.029 .404 & 9.229 .327 & $17,44 \%$ \\
\hline 2006 & 54.282 .533 & 6.430 .460 & 2.839 .964 & 9.270 .424 & $17,08 \%$ \\
\hline 2007 & 55.877 .855 & 6.681 .275 & 2.767 .152 & 9.448 .427 & $16,91 \%$ \\
\hline 2008 & 57.656 .117 & 6.746 .274 & 2.478 .686 & 9.224 .960 & $16,00 \%$ \\
\hline 2009 & 58.646 .432 & 6.978 .415 & 2.318 .799 & 9.297 .214 & $15,85 \%$ \\
\hline
\end{tabular}

Fonte: Elaboração própria a partir dos dados da Caixa Econômica Federal, 2012.

Ao tratarmos do assunto relativo ao mercado Imobiliário, a princípio temos que ter o cuidado em compreender que o termo "imobiliário" remete a um conceito de mercado mais amplo do que o apresentado com o termo "habitacional", pois inclui as operações realizadas para a construção de

\footnotetext{
${ }^{2}$ Para melhor compreender os cálculos da demanda potencial vide Caixa Econômica Federal (2012) - Demanda Habitacional no Brasil.
}

RE\&D Econ. e Desenv., Santa Maria, vol. 27, n.2, p. 276 - 296, jul. - dez. 2015 
imóveis comerciais e toda a gama de edificações que não se enquadram no conceito habitacional. Porém, de acordo com os dados do Banco Central relativos ao volume de dinheiro utilizado nas operações de financiamento com dados consolidados para o ano de 2012, tanto nos empréstimos dentro do SFH quanto nas taxas de mercado, foi constatado que $92,69 \%$ de todo o financiamento é realizado nas obras de habitação. Portanto, sempre que for utilizado o termo imobiliário, o conceito estará ligado principalmente à construção de imóveis residenciais.

A partir de 2002, foi constatado que a inadimplência no setor começou demonstrar uma trajetória de declínio, os dados sobre inadimplência foram retirados da base de dados do Banco Central considerando os contratos que registraram falta de pagamento a partir de três prestações. Essa trajetória foi bastante acentuada entre os anos de 2006 e 2007, período em que a economia brasileira manteve um bom ritmo de crescimento. Fatos como a melhoria salarial, redução nas taxas de juros, aumento do emprego, além de um excelente cenário econômico externo, estavam tendo influência direta para a diminuição da inadimplência que em 2002 era em torno de 51,93\% caindo para 34,72\% ao final de 2007.

Outro fator de ordem conjuntural foi o processo de redução gradual da taxa SELIC, em dezembro de 1997, um mês após a criação do SFI, a taxa básica de juros era de 39,87\%, em 2007 essa taxa chegou a $11,18 \%$. Como a SELIC é uma taxa referencial para a economia, uma redução na mesma também provoca a redução de todas as taxas de juros inclusive aquelas referentes ao financiamento imobiliário, beneficiando também os financiamentos realizados sobre as taxas de mercado.

\section{GRÁFICO 4 - EVOLUÇÃO DO NÚMERO TOTAL DE UNIDADES IMOBILIÁRIAS FINANCIADAS}

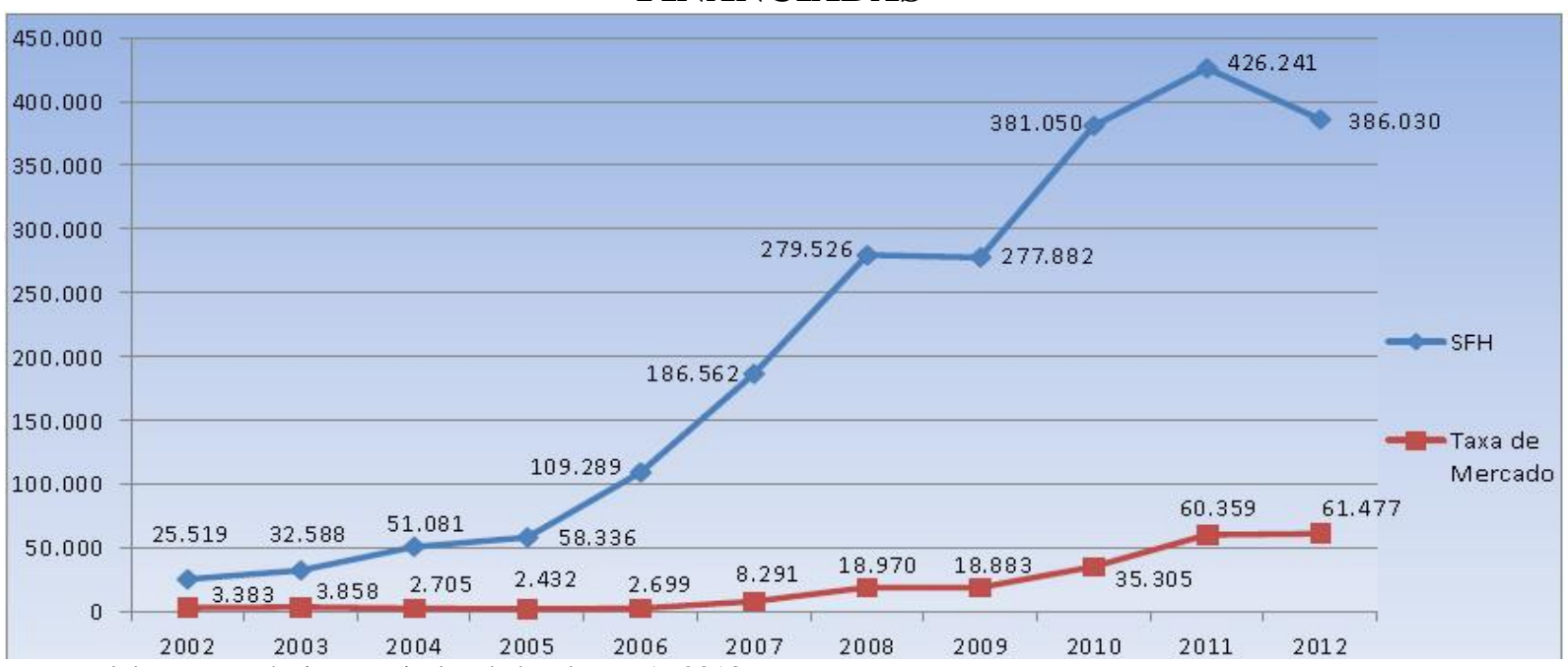

Fonte: Elaboração própria a partir dos dados do IPEA, 2013.

Devido à crise, a partir do segundo trimestre do ano de 2008 o governo incentivou a ampliação da carteira de crédito dos bancos públicos, devido a grande contração provocada pelos bancos privados. O governo utilizou a CEF como o principal agente de realização dessas políticas de estímulo a economia através do setor da habitação. A caixa que já administrava o FGTS e tinha recebido em 2007 recursos oriundos do PAC, com o aumento dos incentivos do governo, o banco passou a explorar mais o mercado imobiliário a fim de ampliar seu "marketshare", já que até a época este era um ambiente de crédito pouco explorado pelas instituições (FUNDAP, 2013).

No gráfico 5 é mostrada a evolução dos financiamentos, comparando a captação de recursos através de investimento privado nacional e internacional com relação aos financiamentos realizados a partir dos recursos aplicados pelo governo.

Econ. e Desenv., Santa Maria, vol. 27, n.2, p. 276 - 296, jul. - dez. 2015 RE\&D 


\section{GRÁFICO 5 - EVOLUÇÃO DO FINANCIAMENTO DE ACORDO COM A FONTE DE RECURSO}

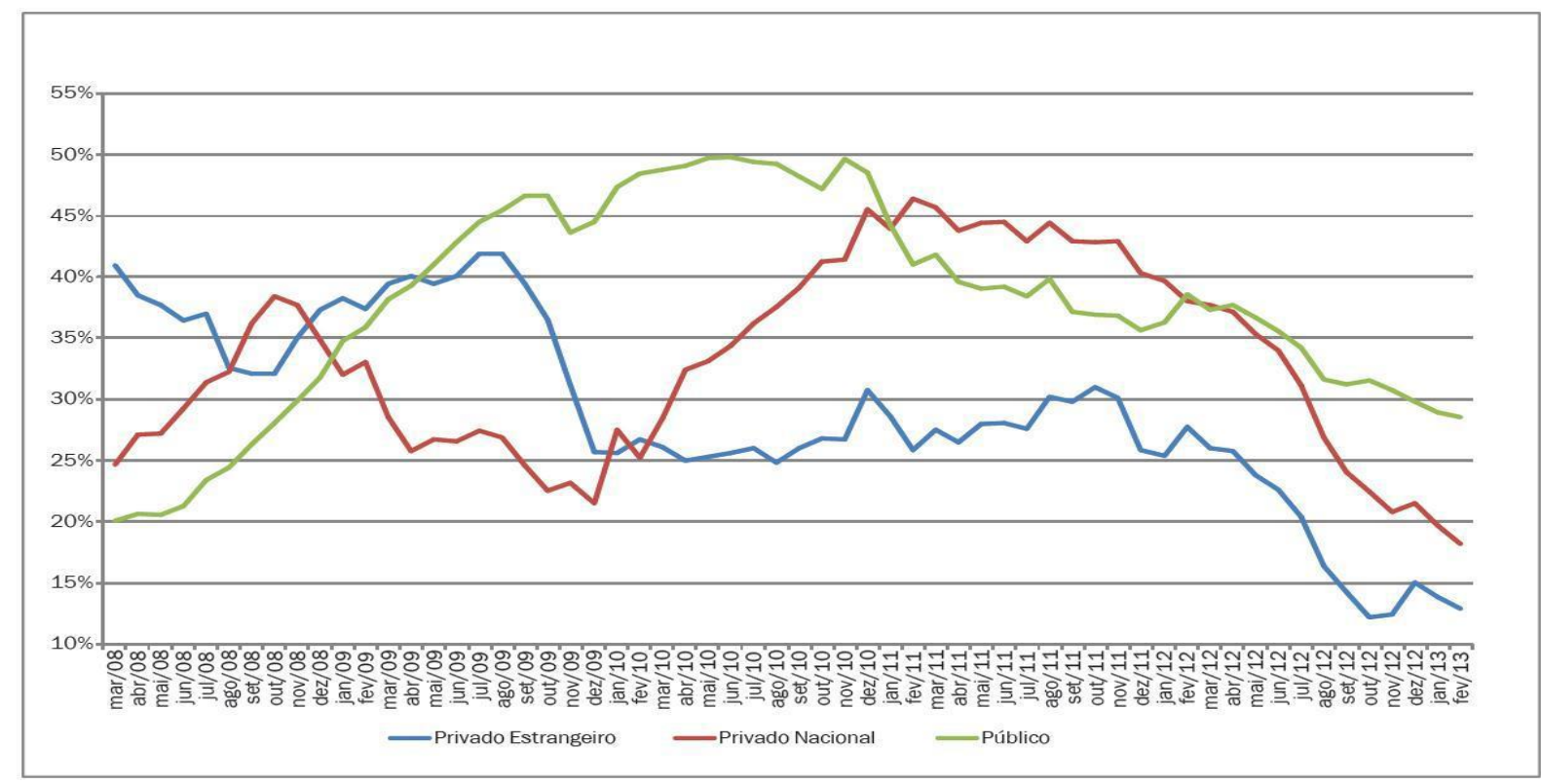

Fonte: FUNDAP, 2013.

Segundo a FUNDAP (2013), fatores de ordem macroeconômica, regulamentares e de diretrizes políticas financeiras foram essenciais para a criação de um ambiente favorável a expansão do financiamento habitacional, isso aumentou o interesse dos bancos em atuar nesse segmento de mercado. Assim, devido a maior competição bancária, foram criados novos produtos e novos canais de distribuição dos financiamentos, como o "Feirão da Casa Própria" feito pela CEF, além de melhorias nas avaliações de risco neste segmento.

A partir de 2010, é dado início a uma nova fase de expansão do financiamento imobiliário. Com a economia retomando o crescimento, o crédito voltou a se ampliar e os resultados das políticas de incentivo ao setor com o PAC e o PMCMV fizeram com que o número de imóveis financiados saltasse de 296.765 em 2009 para 416.355 em 2010. No ano seguinte, essa tendência foi mantida devido a fatores como a ampliação da parcela do imóvel coberta pelo financiamento que em 2005 era de $47,9 \%$ chegando a $90 \%$ para os financiamentos realizados pela CEF, direcionado a população de baixa renda, e $80 \%$ para os financiamentos concedidos pelos bancos privados.

Um grande destaque deve ser dado para aqueles financiamentos realizados a taxas de mercado, pois, em 2011 o número de financiamentos enquadrados no $\mathrm{SFH}$ cresceu 11,86\% enquanto que os financiamentos realizados a taxas não reguladas cresceram 70,96\%. Isso pode ser explicado pelo aumento da concorrência bancária que proporcionou melhores prazos de financiamento, maior cobertura e melhores taxas de juros.

Em 2012, a taxa de crescimento do financiamento imobiliário entra em um processo de reversão bastante expressivo, como pode ser observados no gráfico 5 acima apresentado. Foram financiados 39.093 imóveis a menos do que tinha sido em 2011. A justificativa para toda essa redução esta baseada em dois fatores que são, (i) o aumento progressivo dos valores dos imóveis e o (ii) aumento da dívida imobiliária das famílias. A elevação do preço dos imóveis e o aumento do endividamento das famílias estão ilustrados nos gráficos 12 e 13, a seguir:

(i) Como a grande maioria dos financiamentos é realizada pelo $\mathrm{SFH}$, com a aceleração dos preços dos imóveis os financiamentos não estão conseguindo se enquadrar nos critérios de exigibilidade do sistema; (ii) $\mathrm{O}$ aumento do endividamento das famílias está provocando uma

RE\&D Econ. e Desenv., Santa Maria, vol. 27, n.2, p. 276 - 296, jul. - dez. 2015 
reavaliação por parte das instituições financeiras com relação à capacidade de pagamento de dívidas futura.

Ao olharmos o gráfico 6 que mostra a evolução do financiamento imobiliário e separa os financiamentos realizados no âmbito do SFH e os que são realizados a taxa de mercado, será constatado que enquanto as operações no SFH reduziram 9,43\%, como já foi mencionado acima, as operações não reguladas mantiveram um leve crescimento de 1,5\%. Esse pequeno crescimento pode ser explicado pela redução da taxa básica de juros que chegou, em novembro de 2012, a 7,14\% atingindo o seu menor nível desde que a série foi iniciada.

\section{GRÁFICO 6 - EVOLUÇÃO DO PREÇO DOS IMÓVEIS COMPARADO À EVOLUÇÃO DA MASSA SALARIAL NO BRASIL}

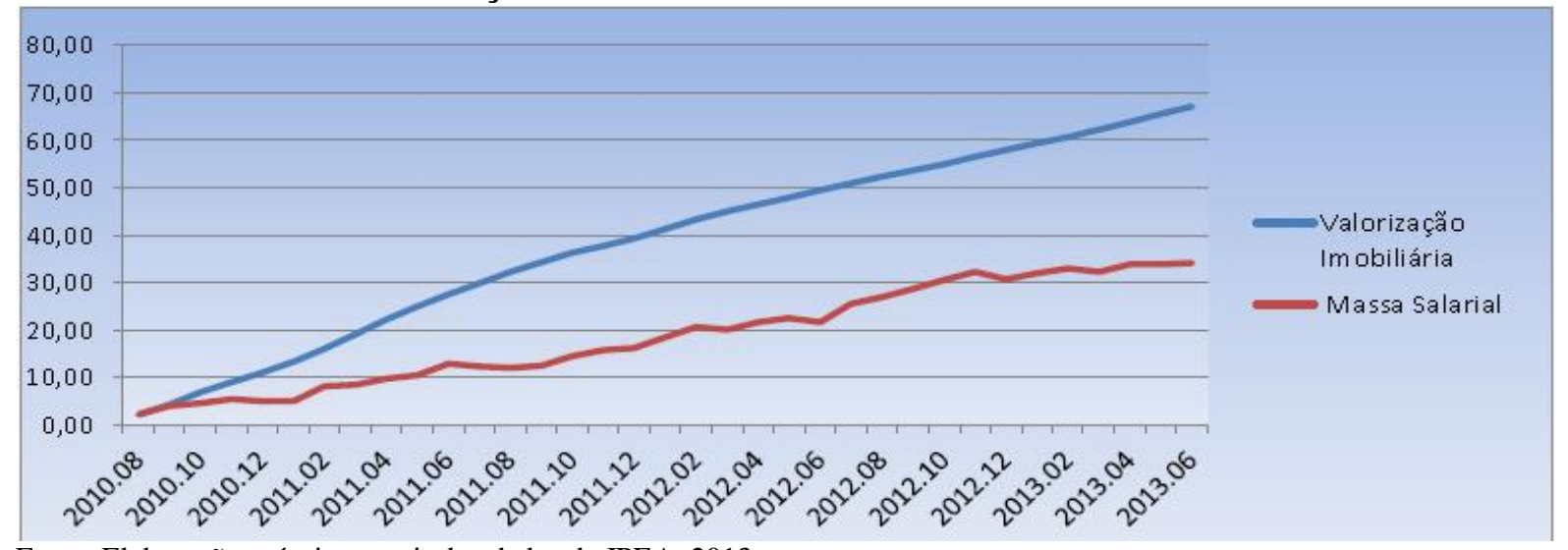

Fonte: Elaboração própria a partir dos dados do IPEA, 2013.

Outro fator interessante é que, apesar de ter reduzido bastante o número de imóveis financiados entre 2011 e 2012, o volume de recursos utilizados nesses financiamentos foram consideravelmente superiores. Para financiar 486.600 unidades, em 2011 foram utilizados um pouco mais de R\$ 79.5 bilhões, em 2012 foram financiadas 447.507 unidades, porém, foram operacionalizados mais de $\mathrm{R} \$ 82,5$ bilhões, ou seja, $\mathrm{R} \$ 2.869$ bilhões a mais para financiar 39.093 imóveis a menos em apenas um ano como está demonstrado no gráfico 7.

\section{GRÁFICO 7 - VOLUME FINANCEIRO UTILIZADO NOS FINANCIAMENTOS - EM BILHÕES}

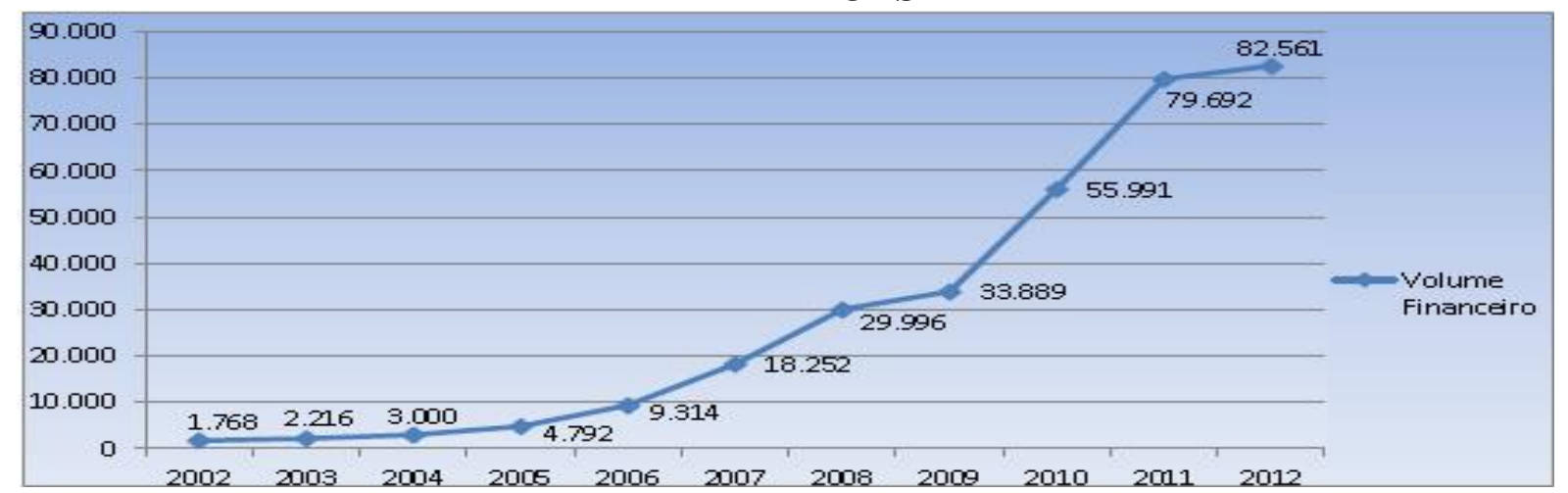

Fonte: Elaboração própria a partir dos dados do IPEA, 2013.

Para analisar um pouco mais o comportamento do mercado imobiliário nos últimos anos, foram utilizados dados extraídos da Câmara Brasileira da Indústria da Construção (CBIC). Esses dados são referente à atividade do mercado imobiliário nas cidades de São Paulo, Recife, Porto Alegre e Belo Horizonte. Os dados extraídos são relativos à velocidade de venda por mês dos imóveis em

Econ. e Desenv., Santa Maria, vol. 27, n.2, p. 276 - 296, jul. - dez. 2015 RE\&D 
cada uma dessas capitais. Para facilitar melhor a compreensão e simplificar os dados, foi realizada uma média das velocidades de vendas mensais, como mostra o gráfico 8.

Entre todas as quatro capitais analisadas, apenas em Recife a velocidade de vendas continuou a crescer entre os anos analisados. A região metropolitana de Recife recebeu muitos investimentos do último governo. Entre esses investimentos estão: a construção de estaleiro e refinaria em Ipojuca, uma fábrica de automóvel instalada em Goiana, entre outros investimentos de menor porte. Com todo esse crescimento, houve, nos últimos anos, principalmente entre 2010 e 2011, um deslocamento muito grande de pessoas que residiam em outros Estados que, devido às novas oportunidades, foram morar em Recife. Isso justifica o crescimento na velocidade de venda dos imóveis, fato que não ocorreu nas outras cidades.

\section{GRÁFICO 8 - VELOCIDADE MÉDIA DA VENDA DE IMOVEIS PARA CIDADES SELECIONADAS}

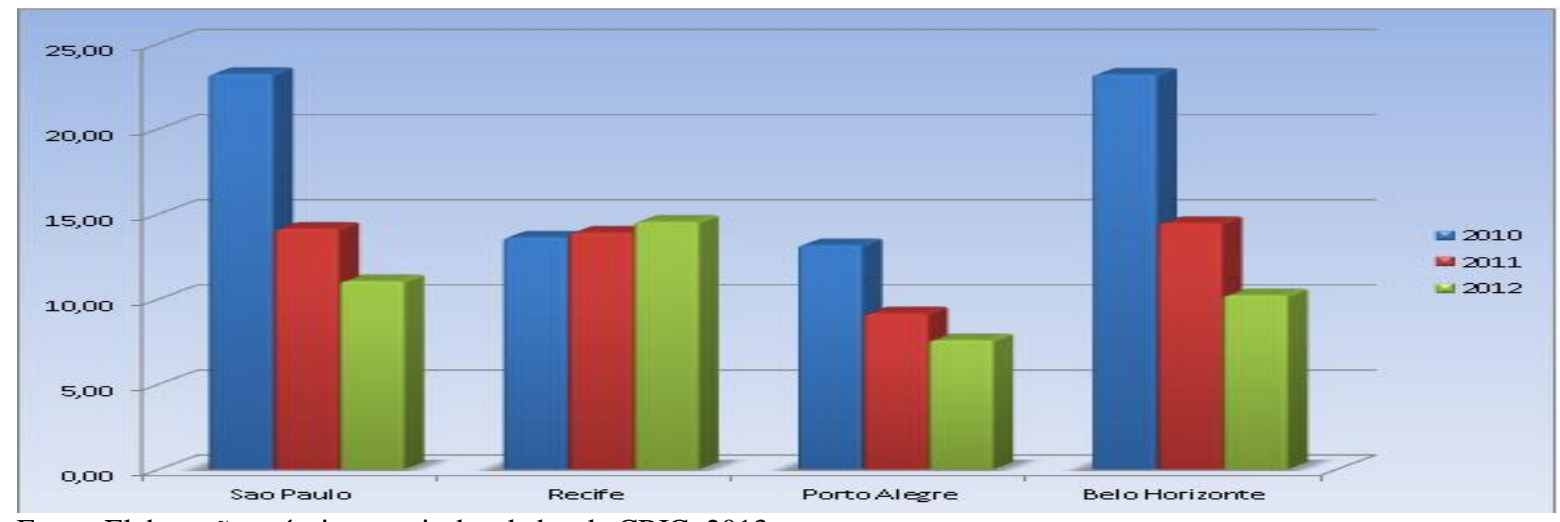

Fonte: Elaboração própria a partir dos dados da CBIC, 2013.

Ao comparar os dados de financiamento para o ano de 2013, a tendência de desaceleração das quantidades de imóveis financiados foi revertida novamente. Partindo de uma análise na qual foram utilizados dados que compreenderam o período entre janeiro a maio, visto que para o presente ano os dados existentes compreendem apenas esse período, ficou constatado que o número de financiamentos imobiliário cresceu 12,58\% em relação a 2012 e 1,81\% com relação a 2011, ano em que foi registrado o maior crescimentos do financiamento desde 1980, quando foram financiados mais de 600 mil unidades residenciais. A elevação do financiamento ocorrida em 2013 esta ilustrada no gráfico 9, abaixo.

\section{GRÁFICO 9 - NÚMERO DE FINANCIAMENTOS IMOBILIÁRIOS REALIZADOS ENTRE JANEIRO E MAIO DE CADA ANO}

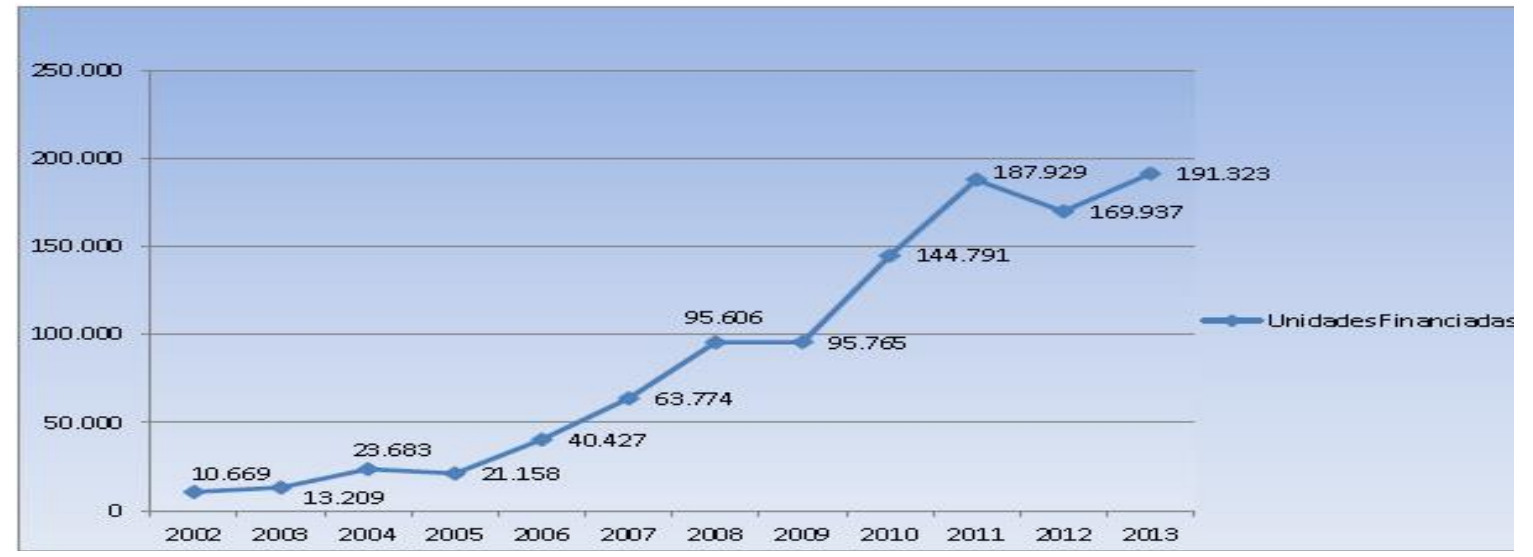

Fonte: Elaboração própria a partir dos dados do Banco Central, 2013.

RE\&D Econ. e Desenv., Santa Maria, vol. 27, n.2, p. 276 - 296, jul. - dez. 2015 
Em outubro de 2012, através da resolução CCFGTS n. 702, o valor máximo de cobertura do valor do imóvel financiado pelo PMCMV foi novamente ampliado, saindo de R\$ 170 mil em 2011 para R 190 mil. Outra medida foi a desoneração da folha salarial dos trabalhadores da construção civil em dezembro de 2012, trazida pela Medida Provisória n. 601, modificada pela Medida Provisória n. 612 de abril de 2013. (FUNDAP, 2013) Com a ampliação da cobertura do financiamento, é aberto mais espaço dentro do sistema que já estava mostrando sinais de desaceleração devido a grande evolução nos preços dos imóveis. A desoneração na construção civil provoca de imediato uma redução ou pelo menos um estacionamento no valor dos imóveis, já que os custos de produção são repassados para o produto. Com os custos reduzindo a tendência é que o preço final também se reduz5sse,

\section{CONSIDERAÇÕES FINAIS}

Ao analisar os modelos de financiamento imobiliário brasileiro a partir da teoria evolucionária e pós-Keynesiana, foi possível identificar os motivos pelas quais o SFH ficou incapacitado de se desenvolver após os anos 90. As formas de captação de recursos se constituíram nos fatores determinantes para a perda de dinamismo do SFH. Sendo assim, foi necessário planejar um novo modelo de financiamento imobiliário para o Brasil. Em 1997 foi criado o SFI baseado em experiências, que para a época, eram bem sucedidas.

O SFI foi criado a partir de uma lógica de financiamento de mercado. A principal inovação tecnológica trazida com o novo modelo foram as companhias securitizadoras de recebíveis imobiliários. O novo sistema pressupunha que o mercado passaria a crescer a partir de investimentos privados. Porém, da forma que foi implantado, não foi possível gerar aqui o mesmo desenvolvimento que foi gerado em outros países. Modificou-se o modelo, ou seja, inovações foram introduzidas, porém, os mecanismos de seleção em grande medida continuaram os mesmo. Não houve nenhuma política que pudesse promover aqui no Brasil uma mudança significativa no mercado. A alienação fiduciária que deveria ter sido implantada junto ao SFI, só passou a funcionar concretamente em 2001 e mesmo após esse período não foi suficiente para tornar o mercado privado majoritário no financiamento imobiliário. Desse modo, o que acabou sendo evidenciado foi que o anteriormente incapacitado SFH foi reforçado e continuou realizando a maior parte dos financiamentos habitacionais.

As iniciativas adotadas pelo governo para estimular a atividade econômica tiveram papel fundamental para o desenvolvimento do mercado de crédito imobiliário nos últimos anos. O SFH, que tinha demonstrado na década de 90 a sua fragilidade diante dos cenários econômicos adversos, encontrou na primeira década do ano de 2000 um novo momento próspero de crescimento, puxado pelo incentivo público como já foi mencionado, mas também através do bom momento econômico que o país estava vivendo. O bom momento econômico do período mencionado acima está ligado à diminuição do desemprego, ao aumento do poder aquisitivo dos brasileiros o que elevou as expectativas de rentabilidade dos investimentos imobiliários e reduziram os riscos de inadimplência. De outro lado a ampliação do acesso ao crédito reduziu os riscos de liquidez das famílias e dos bancos. Nesse ambiente de maior liquidez, os agentes passam a ter expectativas cada vez mais positivas e percepção de riscos decrescentes, e assim não se preocupam tanto em contrair dívidas.

Racionalmente a justificativa é que, diante de um ambiente ruim, a expectativa gerada é que esse ambiente permaneça ruim. Por este motivo é que os bancos emprestam menos e as famílias passam a se endividar menos e inevitavelmente o investimento imobiliário se reduz. Os estímulos dados pelo governo acabaram compensando a piora no cenário econômico.

Econ. e Desenv., Santa Maria, vol. 27, n.2, p. 276 - 296, jul. - dez. 2015 RE\&D 


\section{REFERÊNCIAS BIBLIOGRÁFICAS}

BAHRY, Thaiza Regina; GABRIEL, Luciano Ferreira. A hipótese da instabilidade financeira e suas implicações para a ocorrência de ciclos econômicos. Revista de Economia contemporânea, Rio de Janeiro, v. 14, n. 1, p. 27-60, jan./abr. 2010.

BANCO CENTRAL DO BRASIL. SFH - Dados Estatísticos. Disponível em: <http://www.bcb.gov.br/?RED-SFHESTAT>. Acesso em: 03/08/2013.

BRASIL. Decreto-lei no 2.291, de 21 de novembro de 1986. Extingue o Banco Nacional da Habitação - BNH, e dá outras Providências. Disponível em:

<http://www.planalto.gov.br/ccivil_03/decreto-lei/del2291.htm>. Acesso em: 01/08/2013.

BRASIL, Ministério das Cidades. Diretrizes gerais para aquisição e alienação de imóveis por meio da transferência de recursos ao Fundo de Arrendamento Residencial. Portaria n. 465, de 03 de outubro de 2011. Disponível em:

<http://downloads.caixa.gov.br/_arquivos/habita/mcmv/Portaria_465_FAR_Consolidada_21_01_2013 .pdf>. Acesso em: 01/08/2013

BRASIL, Ministério do Planejamento. PAC 2. Sobre o PAC. Disponível em: <http://www.pac.gov.br/sobre-o-pac>. Acesso em: 15/08/2013.

BROLLO, Fernanda. Crédito imobiliário e déficit de moradias: uma investigação dos fatores econômicos e institucionais do desenvolvimento habitacional no Chile e no Brasil. 2004. 99f. Dissertação (Mestrado) - Escola de Administração de Empresas de São Paulo, Fundação Getulio Vargas, São Paulo, 2004.

CAIXA ECONOMICA FEDERAL. Demanda habitacional no Brasil. Brasília: CAIXA,2011.Disponívelem:<http://downloads.caixa.gov.br/_arquivos/habita/documentos_gerais/dem anda_habitacional.pdf $>$. Acesso: 20/07/2013.

RE\&D Econ. e Desenv., Santa Maria, vol. 27, n.2, p. 276 - 296, jul. - dez. 2015 